\title{
SUPLEMENTO À POÉTICA DE ARISTÓTELES ${ }^{1}$
}

\author{
J. W. von GOETHE \\ Tradução: Oliver TOLLE
}

Quem quer que de algum modo tenha se ocupado da teoria da poesia, e particularmente da tragédia, recordar-se-á de uma passagem em Aristóteles que causou muita dificuldade aos intérpretes, sem que pudessem concordar completamente sobre o seu significado. Numa caracterização mais precisa da tragédia, o grande homem parece esperar dela que, por meio da encenação de ações e acontecimentos que suscitam compaixão e medo, purifique (reinigen) o ânimo do espectador das paixões mencionadas.

Acredito poder comunicar de melhor maneira meus pensamentos e minha convicção sobre a passagem mencionada por meio de uma tradução dela.

\footnotetext{
1 Este texto, que nas edições das obras de Goethe consta em geral nos Schriften zur Literatur [Escritos de literatura], foi publicado pela primeira vez na revista "Über Kunst und Altertum", v.6, caderno I, 1827, p.84-91. Vale destacar nesta nota, de modo breve, a posição de Goethe diante do tema da catarse, talvez um dos assuntos mais discutidos na história da literatura ocidental e da teoria da tragédia: Goethe se afasta da perspectiva que considera a catarse a partir do efeito moralizador que provoca sobre o espectador e a interpreta como um ingrediente interno da composição mesma do poema trágico. Este modo de pensar pode ser compreendido de modo geral como constituindo um rompimento com uma estética do efeito e estabelecendo uma base, por assim dizer, dedutiva especulativa para a poesia dramática, tal como esta tendência de apreciação vem se impondo no pensamento estético alemão desde Lessing e Schiller até os sistemas da filosofia da arte de Schelling e Hegel (N. T.).

2 Mestrando do Departamento de Filosofia da USP. Gostaria de prestar os meus agradecimentos aos professores Marco Aurélio Werle (UNESP) e Victor Knoll (USP), pela leitura cuidadosa da tradução e por suas sugestões sempre oportunas, e ao professor Márcio Suzuki, pela indicação do texto e principalmente pelo estímulo.
} 
A tragédia é a imitação de uma ação significativa e acabada, que possui uma certa extensão e que é declamada em linguagem graciosa, e precisamente por figuras separadas que desempenham cada uma o seu próprio papel, e não narrativamente por um único indivíduo; depois do decurso da compaixão e do medo, porém, encerra a sua tarefa com o equilíbrio de tais paixões. $^{3}$

Por meio dessa tradução, acredito ver esclarecida a passagem considerada obscura até agora, e acrescento ainda o seguinte: Como poderia Aristóteles - nesta sua maneira de apontar sempre para o objeto (Gegenstand) ao falar justamente da construção da tragédia - pensar no efeito (Wirkung) e, o que é ainda mais, no efeito distante que uma tragédia talvez tivesse nos espectadores? De maneira alguma! Ele se expressa de modo inteiramente claro e correto: tendo a tragédia transposto o decurso de meios inspiradores de compaixão e medo, deve por último encerrar o seu trabalho no teatro com o equilíbrio, com a reconciliação, de tais paixões.

Ele entende por catarse (Katharsis) este arremate reconciliador (aussöhnende Abrundung), o qual, afinal de contas, é exigido por todo drama e mesmo por todas as obras poéticas.

Na tragédia, ele ocorre por meio de uma espécie de sacrifício humano, seja este consumado efetivamente ou solucionado sob a influência de uma divindade favorável por meio de um sucedâneo, tal como no caso de Abraão e Agamenon; em suma, se a tragédia quiser ser uma obra literária perfeita, uma conciliação, uma solução, é indispensável para a conclusão. Esta solução, todavia, influenciada por um desfecho favorável e desejado, já se aproxima do gênero médio, tal como o retorno de Alceste; na comédia, em contrapartida, para o desfecho de todos os embaraços, que são o que há de ínfimo no medo e na esperança, intervém comumente o casamento, o qual, mesmo que não dê término à vida, faz nela um corte significativo que deve ser considerado. Ninguém quer morrer, mas todos querem se casar, e nisso reside a diferença em parte divertida em parte séria entre a tragédia e a comédia da estética aristotélica.

3 Tradução feita com base na tradução de Goethe. Já na tradução do helenista Eudoro de Souza, feita diretamente do grego, lemos: "É pois a tragédia imitação de uma ação de caráter elevado, completa e de certa extensão, em linguagem ornamentada e com várias espécies de ornamentos distribuídas pelas diversas partes [do drama], [imitação que se efetua] não por narrativa, mas mediante atores, e que, suscitando o terror e a piedade, tem por efeito a purificação dessas emoções" (1449b, 24-27, In: Aristóteles. Poética, "Os pensadores", São Paulo, Abril Cultural, p.205). (N. T.) 
Além disso, reparamos que os gregos utilizaram a sua trilogia para tal finalidade: pois não existe catarse mais elevada que aquela do "Édipo em Colonos", em que um criminoso semiculpado, um homem que por meio de constituição demoníaca, por meio de uma impetuosidade sombria de sua existência, justamente na grandeza de seu caráter, por meio do exercício constantemente precipitado do crime, se dirige para as mãos das potências conseqüentes eternamente imperscrutáveis, incompreensíveis, lança a si e aos seus na mais profunda e irreparável miséria, e mesmo assim é, ainda, reconciliador e reconciliado, elevado à condição de aparentado dos deuses, como espírito protetor e abençoador de um país digno de seu próprio sacrifício.

Nisso também se apóia a máxima do grande mestre de que os heróis da tragédia não têm de ser apresentados nem inteiramente culpados nem inteiramente livres de culpa. No primeiro caso, a catarse seria apenas um choque, e o malfeitor assassinado, por exemplo, apenas pareceria ter escapado à justiça comum; no segundo caso, ela não é possível: pois no destino ou no que influencia o humano recairia a culpa de uma injustiça demasiadamente pesada.

De resto, não gostaria de me comportar de modo polêmico nesta ocasião como em muitas outras; todavia, tenho de expor como se buscou interpretar até agora esta passagem. Aristóteles, a saber, disse na "Política" que a música poderia ser usada na educação para fins éticos (sittlichen), porque os ânimos inicialmente despertos em orgias eram acalmados por meio de melodias divinas e, por conseguinte, por meio disso certamente também outras paixões poderiam ser postas em equilíbrio. Que aqui se trate de um caso análogo, não negaremos, mas ele não é idêntico. Os efeitos da música são de espécie mais material, tal como Händel os executou em sua "Festa de Alexandre" e como podemos ver em todo baile em que uma valsa tocada segundo uma polonaise modesta e elegante arrebata toda a juventude para um delírio baquiano.

Contudo, a música pode tão pouco quanto qualquer arte atuar sobre a moralidade (Moralität), e é sempre falso quando se espera dela tais resultados. Apenas a filosofia e a religião são capazes disso; piedade e dever têm de ser estimulados e apenas casualmente tais estímulos são atribuídos às artes. O que está ao seu alcance é um abrandamento de costumes rudes, que todavia logo degeneram em efeminação.

Quem, pois, avança no caminho de uma formação interior verdadeiramente ética (sittlichen) sentirá e concordará que de maneira alguma tragédias e romances trágicos acalmam, mas sim transmitem inquietação ao ânimo e àquilo que chamamos de coração e vão ao encontro de uma 
condição vagamente indeterminada; a juventude gosta dessa condição e, por isso, é arrebatada apaixonadamente por tais produções.

Retornamos ao nosso começo e repetimos: Aristóteles fala da construção da tragédia, desde que o poeta, erigindo-a como objeto, pense em produzir, de modo acabado, algo encantador, digno de ser visto e ouvido.

Se o poeta cumpriu com a sua obrigação no que lhe cabe, tendo dado um nó significativamente e desatando-o apropriadamente, então isso se sucederá no espírito do espectador; o enredo lhe causará confusão, o desfecho o esclarecerá, mas em nada melhorado ele voltará para casa: muito mais ele se admiraria consigo mesmo se fosse suficientemente cuidadoso e ascético em relação ao fato de que de volta ao lar se encontra tão imprudente e obstinado, impetuoso e débil, afetuoso e carente, como quando saiu dele. E assim cremos ter dito tudo o que diz respeito a este ponto, embora este tema permita que ainda mais coisas sejam esclarecidas por meio de uma exposição ulterior. 